PREDICTING THE UNPREDICTABLE 



\title{
PREDICTING THE UNPREDICTABLE
}

\author{
The Tumultuous Science of \\ Earthquake Prediction
}

Susan Elizabeth Hough

with a new preface by the author

Princeton University Press Princeton E Oxford 
Copyright (C) 2010 by Princeton University Press

Published by Princeton University Press, 41 William Street, Princeton, New Jersey 08540

In the United Kingdom: Princeton University Press, 6 Oxford Street, Woodstock, Oxfordshire OX20 1TR

All Rights Reserved

Third printing, first paperback printing, with a new preface by the author, 2016

Paperback ISBN: 978-0-691-17330-6

The Library of Congress has cataloged the cloth edition as follows:

Hough, Susan Elizabeth, 1961-

Predicting the unpredictable : the tumultuous science of earthquake prediction / Susan Hough.

p. $\quad \mathrm{cm}$.

Includes bibliographical references and index.

ISBN 978-0-691-13816-9 (hardcover : alk. paper) 1. Earthquake prediction.

I. Title.

QE538.8.H68 2010

551.22 -dc22 2009008380

British Library Cataloging-in-Publication Data is available

This book has been composed in Bembo and Berthold Akzidenz Grotesk

Printed on acid-free paper. $\infty$

press.princeton.edu

Printed in the United States of America

$\begin{array}{llllllll}10 & 9 & 8 & 7 & 6 & 5 & 4 & 3\end{array}$ 